\title{
Pulmonary talc granulomatosis mimicking lung cancer
}

\author{
Dieter Scholtze, ${ }^{1,2}$ Christine Angelika Rueegg $^{1}$
}

'Division of Pulmonary Medicine, Stadtspital Triemli, Zurich, Switzerland

${ }^{2}$ Department of Medicine, University of Zurich, Zurich, Switzerland

\section{Correspondence to} Dr Dieter Scholtze dieter.scholtze@triemli.zuerich. ch

Accepted 29 March 2019

\section{DESCRIPTION}

A 46-year-old man with a history of cough and night sweats extending over 4 weeks was admitted because of new-onset chest pain. Blood analysis highlighted elevated inflammatory markers. CT showed a spiculated lung mass, highly suspicious of malignancy (figure 1, arrow). Histopathology of bronchoscopy-guided transbronchial biopsies revealed no malignancy but giant cell granulomas around birefringent material (figure 2, arrow). On admission, the patient denied intravenous drug use. Despite antibiotic treatment with amoxicillin/clavulanic acid and clarithromycin, fever occurred after a week. CT evidenced abscessing pneumonia and empyema (figure 3, arrow). A chest tube was placed and antibiotics were switched to piperacillin-tazobactam for 2 weeks and clindamycin for 3 weeks, consecutively. The patient responded well to this treatment with a decrease of fever and chest pain, and normalisation of the inflammatory markers. Two months later, CT demonstrated complete resolution of the lung mass and empyema (figure 4). After all, the patient eventually admitted having repeatedly injected crushed morphine tablets dissolved in water. Accordingly, the initial findings of the CT scan and the lung biopsy were interpreted as pulmonary talcosis, a granulomatous disease of the lung caused by intravenous misuse of oral drugs. Injected material had embolised into the lung and had caused foreign body reaction (talc granulomatosis), mimicking lung cancer. Due to superinfection, empyema had evolved.

Pulmonary talc granulomatosis (or pulmonary talcosis) is a rare condition. In the past, it was the result of the inhalation of talc dust. In the 1960s,

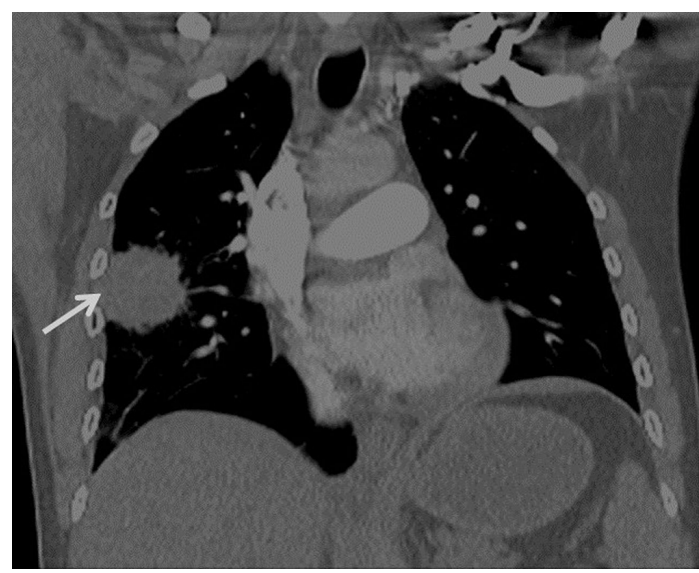

Figure $1 \mathrm{CT}$ images showing spiculated mass in the right lung measuring $6,6 \times 4,5 \times 3,9 \mathrm{~cm}$ with close contact to pleural space (arrow).

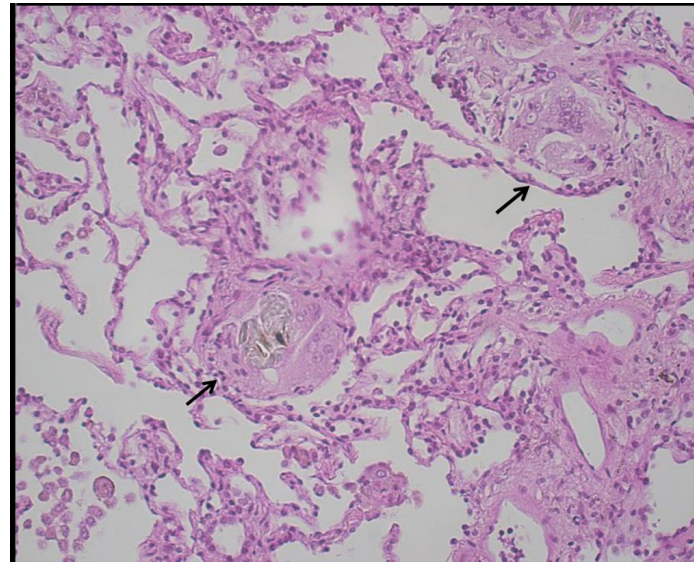

Figure 2 Transbronchial biopsies with no malignancy but vascular and interstitial giant cell granulomas around birefringent material (arrow).

pulmonary talcosis emerged as a new phenomenon caused by intravenous injection of dissolved oral medication and at last by illegal drug abuse, such
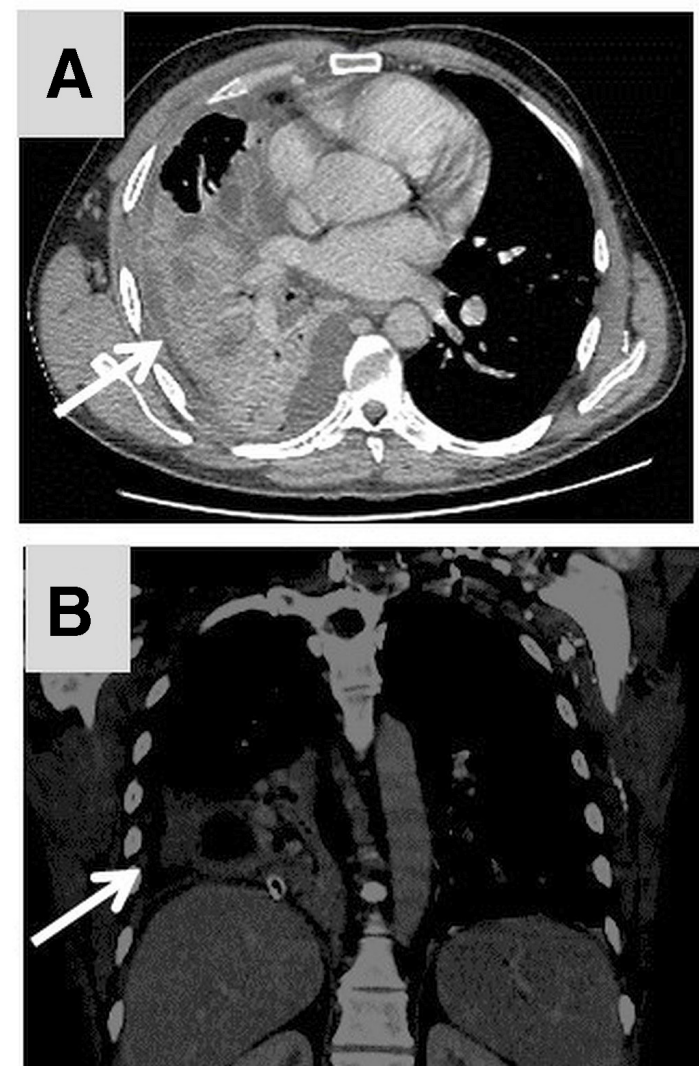

Figure 3 CT images demonstrating abscessing pneumonia and empyema (arrow). 


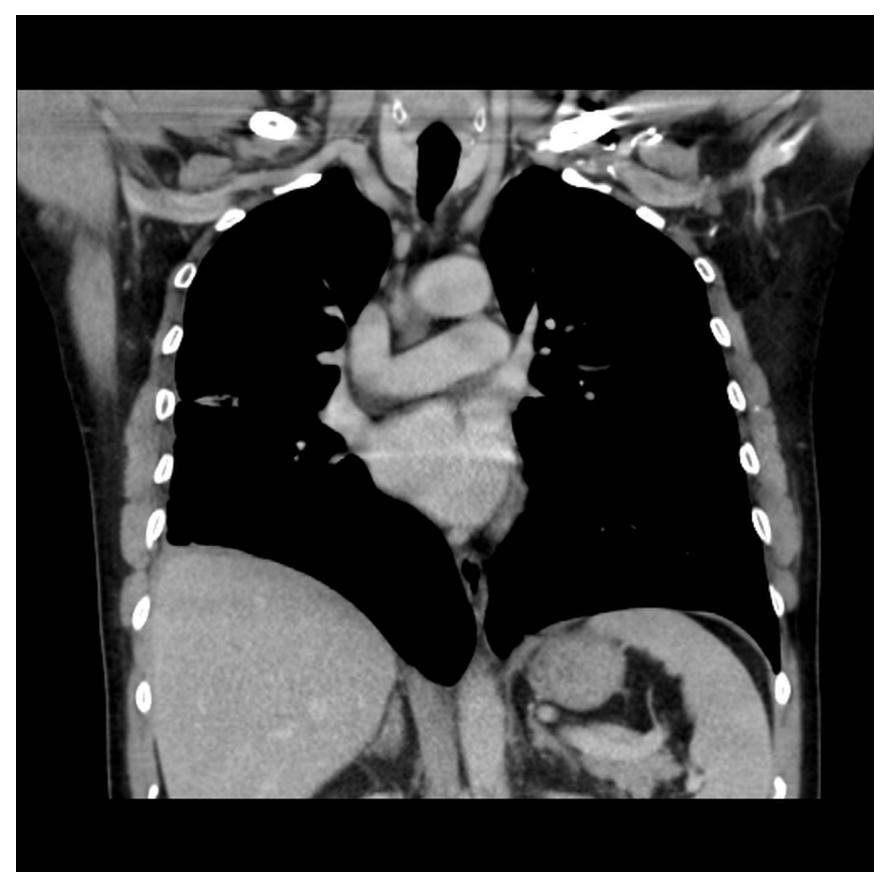

Figure $4 \mathrm{CT}$ images demonstrating complete resolution of the lung mass and empyema.

as cocaine. ${ }^{1}$ Frequently these drugs are elongated with talc to increase the mass and especially the costs. Talc (magnesium silicate) is a common bulking agent in oral medications. In drug users, who intravenously inject medications intended for oral use, small particles of talc reach the pulmonary vessels and can cause foreign body granulomatous reaction in the pulmonary interstitium. ${ }^{2}$ Foreign-body granulomatous reactions have also been described in other organs, such as liver, spleen, retina, kidney, skin, pancreas, lymph nodes and bone marrow. ${ }^{3}$
Because pulmonary talcosis has a very low incidence, the diagnosis can be a challenge. Talc can lead to interstitial fibrosis and in some cases to intravascular talcosis in the pulmonary arteries. ${ }^{45}$ In the present case, an extensive formation of pulmonary talcosis mimicked a neoplasia by forming a solitary lung mass, which is a rare feature.

\section{Learning points}

- A malignancy is not always a malignancy.

- Illegal drug abuse can make a lot of special and rare complications.

- Sometimes you have to ask three or four times to get the right answer.

Contributors DS and CAR designed and directed the project, treated the patient, make the literature research, and wrote the article.

Funding The authors have not declared a specific grant for this research from any funding agency in the public, commercial or not-for-profit sectors.

Competing interests None declared.

Patient consent for publication Obtained.

Provenance and peer review Not commissioned; externally peer reviewed.

\section{REFERENCES}

1 Arnett EN, Battle WE, Russo JV, et al. Intravenous injection of talc-containing drugs intended for oral use. A cause of pulmonary granulomatosis and pulmonary hypertension. Am J Med 1976;60:711-8.

2 Matrosovich E, Brodmann R, Lampert S, et al. Dyspnea following intravenous drug use. Respir Med Case Rep 2017:20:192-4.

3 Marchiori E, Lourenço S, Gasparetto TD, et al. Pulmonary talcosis: imaging findings. Lung 2010;188:165-71.

4 Marchiori E, Zanetti G, Mano CM, et al. Talc-induced pulmonary granulomatosis or septic pulmonary embolism? A diagnostic challenge. Ann Thorac Surg 2010;90:362-3.

5 Reverso-Meinietti J, Vandenbos F, Risso K, et al. [Pulmonary intravascular talcosis: A case report]. Rev Med Interne 2018;39:658-60.

Copyright 2019 BMJ Publishing Group. All rights reserved. For permission to reuse any of this content visit

https://www.bmj.com/company/products-services/rights-and-licensing/permissions/

BMJ Case Report Fellows may re-use this article for personal use and teaching without any further permission.

Become a Fellow of BMJ Case Reports today and you can:

- Submit as many cases as you like

- Enjoy fast sympathetic peer review and rapid publication of accepted articles

Access all the published articles

- Re-use any of the published material for personal use and teaching without further permission

For information on Institutional Fellowships contact consortiasales@bmjgroup.com

Visit casereports.bmj.com for more articles like this and to become a Fellow 